\section{Sciensage}

Journal of Advanced Scientific Research

Available online through https: / /sciensage.info
ISSN: 0976-9595

Review Article

DOI: $10.55218 /$ JASR.202213103

\title{
A REVIEW ON POLYHERBAL FORMULATION USED IN THE TREATMENT OF RHEUMATOID ARTHRITIS
}

\author{
Basant Khare*, Tarkeshwar Prasad Shukla \\ Faculty of Pharmacy, Oriental University, Indore, Madhya Pradesh, India \\ *Corresponding author: basant.khare08@gmail.com
}

\begin{abstract}
Rheumatoid arthritis (RA) is a progressive, chronic, debilitating autoimmune disease manifested clinically by polyarthralgia associated with joint dysfunction triggering the antibodies targeting against the self-neoepitopes determined by autoimmune responses associated with chronic arthritic attacks. Arthritis is not an inherited disease but caused by stimulation of some hidden arthritis susceptible genes lowering the quality of life throughout the world, particularly in developing countries. RA generally affects the joints like wrists, elbows, knees and ankles. Usually women are more affected by RA than men due to the prevalence of hormonal changes. Age is also an important factor that contributes for the development of RA. Several anti-inflammatory and disease-modifying drugs are available for RA therapy. However, the prolonged use of these drugs is associated with severe side effects. Furthermore, these drugs are effective only in a proportion of RA patients. Hence, there is a need to search for new therapeutic agents that are effective yet safe. Interestingly, a variety of herbs and other natural products offer a vast resource for such anti-arthritic agents. Nature has been a source of medicinal agents for more than thousands of years and herbal therapy predominates in traditional systems of medicine as well as in alternative medicine practiced in various cultures such as Indian system of medicine, Chinese Traditional Medicine, Unani classical literature. This review article presents about various polyherbal formulations (PHF) utilized in RA treatment. PHF has been used all around the earth due to its medicinal and therapeutic application. The present review deals with various commercial and non-commercial polyherbal formulation used by different countries of the world for the treatment of RA, their therapeutic potentials including clinical and preclinical results along with their safety and efficacy. This review will facilitate to gain all about the past scientific research and the necessary information about the anti-arthritic activities of polyherbal formulations which will insist the young researchers for future research to protect human beings from RA and may serves as a natural gold for the promotion of mankind.
\end{abstract}

Keywords: Rheumatoid arthritis, Polyherbal formulation, Phytochemicals, Autoimmune diseases, Synergistically, Ethno medicinal.

\section{INTRODUCTION}

Immune system of our body plays a crucial role, as an overactive immune system may lead to certain fatal disease because of various hypersensitive or allergic reactions which may cause numerous derangements; loss of normal capacity to differentiate self from non-self resulting in immune reactions against our own's cells and tissues called autoimmune diseases. Certain common autoimmune diseases like myasthenia gravis, serum sickness, pernicious anemia, reactive arthritis etc., are the severe issues for medical and pharmaceutical community because of unknown etiology [1]. Arthritis is derived from two words; arth meaning joint and ritis meaning inflammation. Arthritis, a chronic, debilitating disorder, affects the musculoskeletal system and it is a very common disease [2]. Arthritis is more prevalent in older than younger people and it has about one hundred types, the most common of which are rheumatoid arthritis and osteoarthritis [3]. Arthritis affects weight bearing joints (knee, hips, feet and spine), synovial joint lining, peri-articular bone and adjacent supporting connective tissue elements [4]. It has been treated by external and internal treatments [5]. The initial symptoms of arthritis are stiffness, swelling and pain [6], which is progressively converted to a chronic disease [7]. It is not inherited from one generation to other; however, some people have hidden arthritis susceptible genes. 


\subsection{Types of arthritis}

\subsubsection{Rheumatoid arthritis}

RA is an autoimmune disease in which the body's immune system which normally protects its health by attacking foreign substances like bacteria and viruses mistakenly attacks the joints. Development of pannus tissue characterizes rheumatoid arthritis. Underlying articular cartilage is destroyed by invasion of this tissue thus leading to rheumatoid arthritis [8]. More than 21 million people in the world are affected by arthritis and $0.5-1 \%$ of this number is suffering from rheumatoid arthritis. Females are more vulnerable to rheumatoid arthritis in comparison to males. Symptoms of rheumatoid arthritis include asthenia, fever, fatigue, weight loss and myalgia [9]. Patients of rheumatoid arthritis are also vulnerable to attack from other diseases such as anaemia, osteoporosis and diseases related to skin and lungs [10]. Almost $>30 \%$ of RA patients suffer from anemic conditions leading to fatigue and tiredness [11]. Rheumatoid arthritis is prevalent in India and Thailand $[12,13]$. Its prevalence is increasing day by day in Thailand [14] affecting 4 out of 1000 individuals, especially women where the percentage is four times higher than men which might be possibly attributed to a difference in immunity levels. A series of surveys by Zeng et al. [15] reported that prevalence of rheumatoid arthritis in China is $0.2-0.37 \%$ without any differentiation among Southern and Northern regions. This disease prevails in urban areas compared to rural areas due to genetic and socioeconomic risk factors. Any infection or other environmental factor can stimulate these genes which can lead to arthritis. The immune system acts negatively and instead of protecting, starts attacking the joints and triggers the development of rheumatoid arthritis. Normally, the lining of a joint is very thin and has very few blood vessels and white blood cells, but in rheumatoid joints, the lining becomes thick and the number of vessels and white blood cells is increased. Interlukin-1 and TNF-alpha (tumor necrosis factor) are secreted by white blood cells. They cause swelling, pain and joint destruction [16]. Recently, novel cytokines, such as Interleukin-18, Interleukin-17 and Receptor activator of nuclear factor kappa-B ligand were discovered in the arthritis pathogenesis [17]. Various genetic and environmental factors cause various phenotypes and are associated with the complex pathway of arthritis. Cytokines perpetuate the complement system and immune complex which cause the onset of rheumatoid arthritis. Immune complexes are affected by metalloproteinases. CD4+T-cells are activated by antigens and then stimulate macrophages, monocyte and synovial fibroblasts. As a result, TNFa cytokines interlukin- 6 and interlukin- 1 are produced. Cell surface signaling boosts the secretion of matrix metalloproteinases [9]. At the start of rheumatoid arthritis, synovial fluid has a large number of neutrophils. Projections are formed by hyperplasia and hypertrophy into joint capsule, $\operatorname{IgG} / \mathrm{anti}-\operatorname{IgG}$ antigenantibody complexes are immune complexes found in synovial fluid [18]. Key pathogenic markers of arthritis are rheumatoid factors (IgM and IgA) [19].

\subsubsection{Osteoarthritis}

Osteoarthritis is the most common form of arthritis, affecting millions of people worldwide. It occurs when the protective cartilage on the ends of bones wears down over time. If coupling between degradation and synthesis of articular cartilage is not stable due to a biological event, arthritis is caused. Although osteoarthritis can damage any joint in the body, the disorder most commonly affects joints in the hands, knees, hips and spine. Osteoarthritis (third in the list of preference) is a leading cause of disability in the world. About $9.6 \%$ of men and $18 \%$ of women with an age above 60 years have osteoarthritis. Most Asian countries have rapid ageing which is the major cause of arthritis especially osteoarthritis [20]. However, hip osteoarthritis in Asian elderly people (Chinese) is 80$90 \%$ less as compared to white people because of genetic and environmental effects [21]. Its symptoms include swelling, pain and stiffness in the arthritic joints as a result of destruction of articular cartilage [22]. Historically, it was thought that osteoarthritis is a wear and tear disease due to the age factor but later on diagnosis of its symptoms in young patients contradicted this thought [23].

\subsubsection{Other types}

Ankylosing spondylitis is one of the systemic diseases predominantly of young men, involving the lumbar spine and sacroiliac joints. This disease is characterized by inflammation and the spine becomes fused to form a rigid structure mainly affecting hip, knee, ankle and shoulder [24]. Systemic Lupus Erythematosus is a polyarticular joint disease, occasionally progressing to a deforming chronic disease. Wrists, knees and fingers are mostly affected [3]. Juvenile arthritis refers to Juvenile rheumatoid arthritis as well as Juvenile chronic arthritis or juvenile idiopathic arthritis. The peak onset of Juvenile arthritis is 1- 3 years and in teenagers. Females 
are more prone to it than males. The knee is the most commonly affected joint. Juvenile arthritis may be rheumatoid factor positive or negative. The cause for Juvenile arthritis is unknown. Infections of environmental pathogenesis also seem to be attributable to Juvenile arthritis pathogenesis [25].

\subsection{Currently used drugs for arthritis therapy and their limitations}

There are multiple drugs currently being utilized to treat RA patients. The most widely used class of drugs is the non-steroidal anti-inflammatory drugs (NSAIDs). There are several different drugs under this category, including Ibuprofen, Aspirin and Naproxen. A majority of them target and suppress prostaglandins (PGs) through inhibition of the cyclooxygenase (COX) enzymes. Patients taking NSAIDs may experience a wide variety of symptoms including renal, hepatic and cardiovascular toxicity. Certain COX-2-selective agents can cause myocardial infarction (heart attack) and stroke [26]. The second major class of antirheumatic drugs is the disease-modifying antirheumatic drugs (DMARDs) and they belong to two categories, chemical and biologic [27]. Methotrexate (MTX) is one of the gold standards of therapy for RA and it is a chemical DMARD. There is some evidence that MTX can suppress the production of proinflammatory cytokines $[28,29]$ as well as modulate the levels of specific MMPs. Another proposition that has been corroborated in animal models and humans is the augmentation of adenosine levels through the reduction of adenosine deaminase in lymphocytes [31]. Adenosine exerts its anti-inflammatory properties via inhibiting proinflammatory cytokine production, attenuating neutrophil trafficking to sites of inflammation, and suppressing Th17 cell differentiation, while stimulating Treg differentiation. Adenosine binds to the $\mathrm{A} 2 \mathrm{~A}$ receptor, which is increased on the surface of lymphocytes in RA patients, and exerts its immunosuppressive properties [32]. While the MTX response rate in RA patients is approximately $50 \%$ [33], the long-term use of this drug can lead to liver fibrosis, which in some cases may require a liver transplant for its management [34-36]. The biologic DMARDs include monoclonal antibodies targeting tumor necrosis factor (TNF)- $\alpha$, (anti-TNF- $\alpha$ ) and IL-6 receptor (anti-IL6R), thereby inhibiting these two cytokines that are major players in promoting RA pathogenesis. Anti-TNF- $\alpha$ is currently the standard of care for RA patients and it is widely used either alone or in combination with other drugs such as MTX [37, 38].
Approximately $10-30 \%$ of patients do not respond to initial treatment with anti-TNF- $\alpha$ and another $23-46 \%$ loses responsiveness over time [39]. Moreover, due to the immunosuppressive effect of blocking TNF- $\alpha$, RA patients are at an increased risk of recurrent infections [40]. Anti-IL6R has been shown to be efficacious in suppressing RA [41, 42], and it can be useful in patients not responding to other forms of treatment [43]. However, anti-IL6R has similar side-effects as antiTNF- $\alpha$. Corticosteroids are another group of biologic DMARDs, which has been used for RA therapy for the past several decades [44]. Corticosteroids suppress inflammation by binding to the glucocorticoid receptor (GR), also known as NR3C1 (nuclear receptor subfamily 3 group $\mathrm{C}$ member 1 ), in turn leading to the transcription of multiple genes that inhibit several inflammatory pathways. These genes include glucocorticoid-induced leucine zipper protein (GILZ) and MAP kinase phosphatase-1 (MKP-1), which suppress the nuclear factor kappa light chain enhancer of activated B cells (NF-k B) (and Activator protein 1 (AP-1)) and p38 MAP kinase, respectively. Moreover, corticosteroids can lead to an epigenetic modification of histones, subsequently resulting in reduction in inflammation [45]. Corticosteroids have unwanted side effects, including osteoporosis, peptic ulcer, and increased rate of infections [46, 47].

\subsubsection{Traditional/herbal medicine for arthritis therapy}

While the above-mentioned mainstream drugs are widely prescribed to patients, they have unwanted side effects. Moreover, some of these drugs are quite expensive. Owing to these limitations, an increasing number of patients have started to turn to natural products to relieve symptoms of RA and related ailments [48], with over $36 \%$ of adults in the USA using complementary and alternative (CAM) therapies [49]. Natural products have been studied extensively in multiple different ailments such as cancer, infectious diseases and autoimmunity, etc. However, difficulties in evaluating the efficacy of these products as well as inadequate information about their mechanism of action are among the reasons for skepticism from both the public and professional communities [50, 51]. Therefore, defining the mechanism of action of natural products is a high priority, as also emphasized by National Center for Complementary and Integrative Health (NCCIH)/National Institutes of Health (NIH), USA. Natural products can control arthritic inflammation 
through multiple pathways, for example, inhibition of effectors molecules (e.g., pro-inflammatory cytokines and chemokines), induction of anti-inflammatory mediators (e.g., IL-4, IL-10), regulation of the Th17/Treg balance and modulation of the osteoimmune cross-talk [52-55]. These effects are in turn the outcome of the control of molecular mediators of inflammation such as NF-kB (nuclear factor kappa-lightchain-enhancer of activated B cells), MAPK (mitogenactivated protein kinase), and STAT3 (signal transducer and activator of transcription 3) by the bioactive components of plant-derived or other natural products. Furthermore, natural products can modulate the Th17/Treg balance by controlling the relative levels of key cytokines (e.g., IL-1 $\beta$, IL-6, and TGF- $\beta$ (transforming growth factor- $\beta$ )) and certain transcription factors such as STAT3, ROR $\gamma$ t (RARrelated orphan receptor gamma), IRF-4 (interferon Regulatory Factor 4), and Foxp3 (forkhead box P3) [56]. Similarly, acting via certain cytokines (e.g., IL-17) and other mediators such as RANKL, natural products can influence not only the $\mathrm{T}$ cell response, but also the osteo-immune cross-talk and bone health [57-59]. In this regard, natural products possessing the above properties can serve as potential therapeutic agents to treat RA either alone or in combination with certain mainstream anti-arthritic drugs.

\subsubsection{Polyherbal formulation}

Herb-herb combinations also known as polyherbal therapy have been used in Chinese medicine practice for thousands of years, yet scientific evidence of their therapeutic benefits is lacking [60]. Drug combination often produces a promising effect in treatment of diseases over a single drug. The concept of drug combination has been well established in Western medicine and remarkable success has been achieved over the decades. In recent years, drug combination therapies in cancer and infectious diseases have offered new hope to patients [61]. Naturally occurring herbs and herbal ingredients organized into certain formula have been shown to have potential interaction effects. These include mutual enhancement, mutual assistance, mutual restraint and mutual antagonism [62]. In the Ayurvedic system of medicine mainly polyherbal compounds are used for treatment of various infections. The Unani system of medicine is also gaining global acceptance due to the amazing clinical efficiency of the formulations. Although Unani medicines have long been used, there is negligible documented evidence regarding their safety and effectiveness. The lack of evaluation has, in turn, slowed down the development of regulations and legislations [63]. The practice of herbal medicine spread from Asia to Europe. The Greeks are known to have acquired knowledge of it over the period from 468-377 BC. In turn, the Romans learned of it from the Greeks around $100 \mathrm{BC}$. The Islamic World learned of and began to practice this science around the time the Roman Empire fell, in the $5^{\text {th }}$ century. By the $10^{\text {th }}$ century, the Anglo-Saxon World was practicing herbal science and describing it in writings. Throughout the middle ages, most herbalism was practiced under the authority of the church, which maintained the authority to grow medicinal herbs and to introduce new herbal medicines [64]. List of some important polyherbal formulation used in the treatment of arthritic worldwide is mentioned in table 1 .

1.2.2.1. Advantages of polyherbal formulation over single herb Ayurvedic and herbal medicinal products contain a combination of botanicals; each of these contains a number of chemical compounds that may give the anticipated activity in combination. The increasing interest in the use of plant-based formulations is leading to a fast growing market for Ayurvedic [65]. Herbal medicines are in widespread use and although many believe herbal medicines are safe, they are often used in combination and are drawn from plant sources with their own variability in species, growing conditions, and biologically active constituents. A major hypothetical advantage of botanicals over conventional singlecomponent drugs is the presence of multiple active compounds that together can provide a potentiating effect that may not be achievable by any single compound. PHF have plant-based pharmacological agents which may exert synergistic, potentiative, agonistic antagonistic actions by virtue of its associated diverse active principles themselves. These pharmacological principles work together in a dynamic way to produce maximum therapeutic efficacy with minimum side effects [66]. Based on the nature of the interaction, there are two mechanisms on how synergism acts (i.e., pharmacodynamics and pharmacokinetic) [67]. In terms of pharmacokinetic synergism, the ability of herb to facilitate the absorption, distribution, metabolism and elimination of the other herbs is focused. Pharmacodynamic synergism on the other hand, studies the synergistic effect when active constituents with similar therapeutic activity are targeted to a similar receptor or physiological system. Other than that, it is believed that 
multiplicity of factors and complications cause diseases in most of the cases, leading to both visible and invisible symptoms. Here, combination of herbals may act on multiple targets at the same time to provide a thorough relief [68]. Due to synergism, polyherbalism offers some great benefits which lacks in single herbal formulation. It is evident that better therapeutic effect can be reached with a single multi-constituent formulation. For this, a lower dose of the herbal preparation would be needed to achieve desirable pharmacological action, thus reducing the risk of deleterious side-effects. Besides, PHFs bring to improved convenience for patients by eliminating the need of taking more than one different single herbal formulation at a time, which indirectly leads to better compliance and therapeutic effect. All these benefits have resulted in the popularity of PHF in the market when compared to single herbal formulation [69]. PHFs also having multiple types of molecules against a disease complication so different molecules cure a disease by different mechanism so provide a complete therapy against a disease condition [70].

\subsubsection{Limitations of polyherbal formulation}

When extracts of plants with these constituents are combined together it may show better activity when compared to the individual extract. But at the same time, presence of many constituents may lead to chemical incompatibility which may result in instability [71]. In India, whereas most of the Ayurvedic PHFs are manufactured and exported, the regulation of Ayurvedic herbal preparation manufacturing is somewhat less stringent, despite the establishment of Drugs and Cosmetic Act to control the manufacture and quality control. According to the good clinical practices, toxicity studies and clinical trials on herbal formulations are not mandatory for application of patents and grant of manufacturing licenses to the Ayurvedic herbal formulation manufacturer [72].

\section{Table 1: Polyherbal anti-arthritic formulation}

\begin{tabular}{|c|c|c|c|}
\hline Formulation & Composition of polyherbal formulation & Experimental model & Ref. \\
\hline Triphala & $\begin{array}{c}\text { Emblica officinalis gaertn, Terminalia chebula, } \\
\text { Terminalia bellerica }\end{array}$ & $\begin{array}{l}\text { Complete freund's adjuvant- } \\
\text { induced arthritis }\end{array}$ & 73 \\
\hline Aerosol & Cardiospermum halicacabum, Vitex negundo & $\begin{array}{l}\text { Complete freund's adjuvant- } \\
\text { induced arthritis } \\
\end{array}$ & 74 \\
\hline Ajmodadi churna & $\begin{array}{l}\text { Trachyspermum ammi, Zingiber officinale, Argyreia } \\
\text { nervosa, Terminalia chebula, Embelica ribes, } \\
\text { Cedrus deodara, Plumbago Zeylanica, Piper longum, } \\
\text { Piper nigrum, Anethum graveolens, Saindhavalavana }\end{array}$ & $\begin{array}{l}\text { Complete freund's adjuvant- } \\
\text { induced arthritis }\end{array}$ & 75 \\
\hline Ariflex tablet & $\begin{array}{c}\text { Boswellia serrata, Commiphora mukul, Pluchea } \\
\text { lanceolata, Withania somnifera, Vitex negundo, } \\
\text { Tinospora cordifolia, Ricinus communis, Zingiber } \\
\text { officinale }\end{array}$ & Oral toxicity study & 76 \\
\hline Arthrito & $\begin{array}{c}\text { Alpinia galangal, Asteracantha longifolia, Boswellia } \\
\text { serrata, Cassia fistula, Commiphora mukul, Eclipta } \\
\text { alba, Elettaria caradamomum, Ricinus communis, } \\
\text { Emblica officinalis, Saussurea lappa, Sida cordifolia, } \\
\text { Terminalia bellerica, Terminalia chebula, Vitex } \\
\text { negundo, Withania somnifera }\end{array}$ & $\begin{array}{l}\text { HRBC membrane stabilization } \\
\text { method, Inhibition of protein } \\
\text { denaturation method }\end{array}$ & 77 \\
\hline Arthrum plus capsule & $\begin{array}{c}\text { Boswellia serrata, Pluchea lanceolata, Vitex negundo } \\
\text { Yograj Guggula }\end{array}$ & $\begin{array}{l}\text { Complete freund's adjuvant- } \\
\text { induced arthritis }\end{array}$ & 78 \\
\hline Arthosansar & $\begin{array}{l}\text { Commiphora wightii, Boswellia serrata, Pluchea } \\
\text { lanceolata, Ricinus communis, Zingiber officinale, } \\
\text { Shilajit, Withani somnifera Linn }\end{array}$ & $\begin{array}{l}\text { Complete freund's adjuvant- } \\
\text { induced arthritis }\end{array}$ & 79 \\
\hline $\begin{array}{l}\text { Balapunarnavadi } \\
\text { choornam }\end{array}$ & $\begin{array}{l}\text { Sida cordifolia, Boerhavia diffusa, Solanum indicum, } \\
\text { Solanum Xanthocarpum, Ricinus communis, Tribulus } \\
\text { terestris }\end{array}$ & Protein denaturation method & 80 \\
\hline Balarista ameliorate & $\begin{array}{c}\text { Sida cordifolia, Withania somnifera, Woodfordia } \\
\text { fruticosa, Ipomoea digitata, Ricinus communis, } \\
\text { Alpinia galanga, Elettaria cardamomum, Paederia } \\
\text { foetida, Eugenia caryophyllus, Vetiveria zizanioids, } \\
\text { Tribulus terrestris }\end{array}$ & $\begin{array}{l}\text { Complete freund's adjuvant- } \\
\text { induced arthritis }\end{array}$ & 81 \\
\hline
\end{tabular}


Boswellia carterii Birdw, Cassia obtusifolia, Abelmoschus manihot, Terminalia chebula,

Compound Ruteng

Lamiophlomis rotate, Pyrethrum tatsienense,

Collagen-induced arthritis

82

$$
\text { Tinospora sinensis }
$$

Gaultheria fragrantissima, Cedrus deodara, Mentha

Dazzle ointment

piperita, Narayan oil, Mahamansh oil, Vishgarbh

oil, Capsicum annuum

Complete freund's adjuvantinduced arthritis

Aegle marmelos, Asparagus racemosus Willd,

Curcuma longa, Desmodium gangeticum, Gmelina arborea Roxb, Oroxylum indicum Vent, Pongamia

DF1911, DF2112, DF2813

pinnata, Premna obtusifolia, Solanum anguivi Lam,

Complete freund's adjuvantinduced arthritis

Solanum virginianum, Stereospermum colais,

Terminalia chebula, Tribulus terrestris, Uraria picta

Terminalia chebula, Terminalia bellirica, Emblica

officinalis, Plumbago zeylanica, Herbal processed

mercury, Herbal processed sulfur, Commiphora mukul,

Collagen-antibody cocktail

$(\mathrm{C}-\mathrm{Ab})$ induced arthritis

Ricinus communis, Vachellia nilotica

Dwipantaravacha, Musta, Mahayogaraj Guggul,

Guggul Purified, Sallaki, Shunti, Lasuna,

Ashwagandha, Rasna, Ballataka Purified, Kuchala

Purified, Haridra, Amrita, Shatavari, Shilajit,

Freemodex

Amalaki, Haritaki, Vibhitaki, Katukaronini,

Sameerapannagaras, ahavidwansras, Ela, Twak,

Patra, Maricha, Nirgundi, Neelanirgundi,

Gandhaprasarini, Amrit, Bala, Shigru Indravalli,

Erand,Lajjalu and Arjuna.

C. rotundus, B. diffusa, T. terrestris, Curculigo

Jeevaneeya rasayana

orchioides Gaertn, Mucuna pruriens, W. somnifera, A. racemous, Hygrophila auriculata

\begin{tabular}{cccc}
\hline $\begin{array}{c}\text { Jointeez and } \\
\text { Arthropower }\end{array}$ & - & $\begin{array}{c}\text { Complete freund's adjuvant- } \\
\text { induced arthritis }\end{array}$ & 88 \\
\hline Jointeez & - & $\begin{array}{c}\text { Complete freund's adjuvant- } \\
\text { induced arthritis }\end{array}$ & 89 \\
\hline
\end{tabular}

\begin{tabular}{|c|c|c|c|}
\hline $\begin{array}{c}\text { Balaguluchiadi kashayam } \\
\text { (BgK), } \\
\text { Punarnavadi kashayam } \\
\text { (PuK), } \\
\text { Gugguluthiktam } \\
\text { kashayam (GuK) }\end{array}$ & $\begin{array}{c}\text { Tinospora cordifolia, Indian bdellium, Azadirachta } \\
\text { indica, Justicia adhathoda, Sida cordifolia, } \\
\text { Adenanthera pavonina, Cedrus deodara, Boerhavia } \\
\text { diffusa, A. indica, Adhathoda vasicca }\end{array}$ & Collagen induced arthritic & 90 \\
\hline $\begin{array}{l}\text { Stifain tablet, } \\
\text { Maharasnadi kwath }\end{array}$ & $\begin{array}{l}\text { Stifain tablet:Maharasnadi kvatha, Yograj guggul, } \\
\text { Mahavatvidhwans ras, Ekangvir ras, Sameer pannag } \\
\text { ras, Bacopa monneri, Ricinus communis, Tinospora } \\
\text { cordifolia, Asparagus racemosus, Hyoscymus niger, } \\
\text { Maharasnadi kwath:contain } 26 \text { plant }\end{array}$ & Protein denaturation method & 91 \\
\hline Majoon suranjan & $\begin{array}{l}\text { Lawsonia inermis, Foeniculum vulgare, Capparis } \\
\text { spinosa, Terminalia chebula, Ipomoea turpethum, } \\
\text { Apium graveolens, Zingiber officinalis, Convulvulus } \\
\text { scammony, Colchicum luteum, Cassia angustifolia, } \\
\text { Piper nigrum, Coriandrum sativum, Rosa damascus, } \\
\text { Origanum vulgare, Pyrethrum indicum, Plumbago } \\
\text { zelanicum, Verbascum thapus, Ricinus communis oil }\end{array}$ & $\begin{array}{l}\text { Formaldehyde induced arthritis, } \\
\text { Complete freund's adjuvant- } \\
\text { induced arthritis }\end{array}$ & 92 \\
\hline Myostaal forte & $\begin{array}{l}\text { Boswellia serrata, Commiphora wightii, Withania } \\
\text { somnifera, Curcuma longa, Tinospora cordifolia, } \\
\text { Zingiber officinale, Alpinia galanga, Cyperus } \\
\text { rotundus, Vitex negundo, Dashmoola, Ricinus } \\
\text { communis, Boerhavia diffusa Cedrus deodara }\end{array}$ & $\begin{array}{l}\text { Idiopathic knee osteoarthritis, } \\
\text { arthritis index, visual analogue } \\
\text { scale, global assessment scores }\end{array}$ & 93 \\
\hline
\end{tabular}


Ricinus communis, Pluchea lanceolata, Tinospora cordifolia Boerhavia diffusa, Zingiber officinale

Trachyspermum ammi, Aconitum Hetero-

Rhumavin tablet phyllum, Smilax Glabra, Shuddha Shilajit, Strychnosnux-vomica, Maha Yograj Guggulu, Vitex negundo, Moringa oleifera, Dashmul Kwatha

Boswellia serrata, Commiphora wightii, Alpinia

Rumalaya forte galanga, Glycyrrhiza glabra, Tribulus terrestris, Tinospora cordifolia, Vitex negundo, Zingiber officinale Commiphora mukul, Pluchea lanceolata, Paederia Sudard tablet

foetida, Vitex negundo, Zingiber officinalis, Ricinus communis, Lepidium sativum, Colchicum luteum, Smilax glabra, Strychnous nuxvomica, Mineral pitch Boswellia serrata, Commiphora mukul, Withania somnifera, Vitex negundo, Ricinus communis, Nyctanthes arbortristis, Zingiber offi cinale

Bovine serum denaturation assay

Complete freund's adjuvantinduced arthritis

Complete freund's adjuvantinduced arthritis

Formaldehyde, Complete freund's adjuvant-induced arthritis

Visual analogue scale and western ontario and mcmaster 97

TLPL/AY/03/2008 curcuminoid, Harpagophytum procumbens, Boswellia serrata, Apium graveolens, Zingiber officinale universities osteoarthritis index Tregocel Withania somnifera, Alpinia galanga, Operculina turpenthum, Colchicum luteum, Zingiber officinale UNIM-301 Apium graveolens, Colchicum autumnale, Trachyspermum ammi, Berberis vulgeris Urinile Apis mellifera, Punica granatum, Vitis vinifera

\begin{tabular}{|c|c|}
\hline PHF & $\begin{array}{c}\text { Glycosmis pentaphylla, Tridax procumbens } \\
\text { Mangifera indica }\end{array}$ \\
\hline PHF & $\begin{array}{c}\text { Cissampelos Pereira Linn, Pongamia pinnata } P \\
\text { Vitex negundo }\end{array}$ \\
\hline PHF & $\begin{array}{c}\text { Polygonum glabrum, Canthium dicoccum, } \\
\text { Ochnaobtusata }\end{array}$ \\
\hline
\end{tabular}

\begin{tabular}{|c|c|c|c|}
\hline PHF & $\begin{array}{c}\text { Polygonum glabrum, Canthium dicoccum, Ochna } \\
\text { obtusata, Argyreia nervosa }\end{array}$ & $\begin{array}{l}\text { Complete freund's adjuvant- } \\
\text { induced arthritis }\end{array}$ & 105 \\
\hline PHF & $\begin{array}{c}\text { Zingiber officinale, Colchicum luteum, Strychnos } \\
\text { nux-vomica }\end{array}$ & $\begin{array}{l}\text { Complete freund's adjuvant- } \\
\text { induced arthritis }\end{array}$ & 106 \\
\hline PHF & $\begin{array}{c}\text { Terminalia chebula, Terminalia bellirica, Emblica } \\
\text { officinalis }\end{array}$ & $\begin{array}{l}\text { Complete freund's adjuvant- } \\
\text { induced arthritis }\end{array}$ & 107 \\
\hline Aerosol & $\begin{array}{c}\text { Cinnamomum camphora oil, Mentha Piperita oil, } \\
\text { Trachyspermum ammi oil }\end{array}$ & $\begin{array}{l}\text { Complete freund's adjuvant- } \\
\text { induced arthritis }\end{array}$ & 108 \\
\hline Upanaha choornam & $\begin{array}{c}\text { Acorus calamus, Anethum sowa, Cedrus deodara, } \\
\text { Pluchea lanceolata, Alpania galangal, Ricinus } \\
\text { communis, Nardostachys jatamansi, Saindhava } \\
\text { Lavana, Sesamum indica, Brassica campestris, } \\
\text { Dolichus biflorus, Phaseolus mungo, Phaseolus } \\
\text { vulgaris, Oryza sativa, Panicum sumatrense, } \\
\text { Aquillaria agallocha Roxh, Santalum alba Linn, } \\
\text { Coleus vettiveroides KC Jacob, Sausserria lappa, } \\
\text { Vettiveria zizinoides }\end{array}$ & $\begin{array}{l}\text { Secretion of TNF- } \alpha \text { and NO and } \\
\text { expression of Cox- } 2 \text { genes }\end{array}$ & 109 \\
\hline Rheuma off gold & $\begin{array}{l}\text { Commiphora mukul, Srychnos nux-vomica, Boswelia } \\
\text { sereta, maharasnadi kwath, suvarna bhasma }\end{array}$ & $\begin{array}{l}\text { Complete freund's adjuvant- } \\
\text { induced arthritis }\end{array}$ & 110 \\
\hline Tongbiling (TBL-II) & $\begin{array}{l}\text { Ramulus cinnamomi Cassiae, paeoniae, Radix aconite, } \\
\text { Lateralis Preparata, Achyranthes bidentata Blume, } \\
\text { Celastrus orbiculatus Thunb, Millettia reticulata Benth }\end{array}$ & $\begin{array}{l}\text { Collagen induced arthritis } \\
\text { model }\end{array}$ & 111 \\
\hline $\begin{array}{l}\text { Huo Luo Xiao Ling Dan } \\
\text { (HLXL) }\end{array}$ & $\begin{array}{c}\text { Boswellia carterii Birdw, Commiphora myrrha Engl, } \\
\text { Angelica sinensis, Salvia miltiorrhiza Bge }\end{array}$ & $\begin{array}{l}\text { Complete freund's adjuvant- } \\
\text { induced arthritis }\end{array}$ & 112 \\
\hline
\end{tabular}




\begin{tabular}{|c|c|c|c|}
\hline $\begin{array}{c}\text { Ganghwaljetongyeum } \\
\text { (GHJTY) }\end{array}$ & $\begin{array}{c}\text { Angelica koreanum, Atractylodes chinensis, Aralia } \\
\text { continentalis, Paeonia obovata, Sinomenium } \\
\text { acutum, Clematis mandshurica, Angelica gigas, Poria } \\
\text { cocos, Alisma orientale, Akebia quinata, Citrus } \\
\text { unshiu, Chaenomeles sinensis, Phellodendron } \\
\text { amurense, Glycyrrhiza uralensis, Juncus effuses } \\
\text { Gleditsia sinensis, Lonicera japonica } \\
\text { Taraxacum platycarpum }\end{array}$ & $\begin{array}{l}\text { Synoviocyte proliferation, HIG- } \\
82 \text { cells, Rabbit knee synovial } \\
\text { membrane cells }\end{array}$ & 113 \\
\hline $\begin{array}{l}\text { Ashwashila Amulya joint } \\
\text { care capsules }\end{array}$ & Withania somnifera, Shilajit & $\begin{array}{c}\text { Collagen antibody-induced } \\
\text { arthritis }\end{array}$ & 114 \\
\hline $\begin{array}{c}\text { Himalaya boswellia joint } \\
\text { wellness } 60 \text { vegetable } \\
\text { capsules, Arthrella, } \\
\text { Amulya } \\
\text { joint care capsule, } \\
\text { Aflapin }\end{array}$ & Boswellia serrata & $\begin{array}{l}\text { Inhibition of NF-KB, COX-2 } \\
\text { and LOX-5 }\end{array}$ & $\begin{array}{l}115- \\
118\end{array}$ \\
\hline $\begin{array}{c}\text { BCM-95, Guggulutiktam } \\
\text { kwatham }\end{array}$ & Curcuma longa & $\begin{array}{l}\text { Inhibition of LOX and NF-jB } \\
\text { signaling and suppressing the } \\
\text { inflammatory mediators }\end{array}$ & 119 \\
\hline Guggulutiktam kwatham & Aconitum heterophyllym & $\begin{array}{l}\text { Inhibiting the TLR-4 MYD88 } \\
\text { signalling, blocks the activation } \\
\text { of NF-jB and MAPK further } \\
\text { suppressing the proinflam- } \\
\text { matory mediators }\end{array}$ & $\begin{array}{r}120- \\
121\end{array}$ \\
\hline $\begin{array}{l}\text { Kapiva artho sure juice } 1 \\
\text { L }\end{array}$ & Picrorhiza kurroa & $\begin{array}{l}\text { Reduced levels of inflammatory } \\
\text { cytokines (TNF-a, IL-10, IL-1b } \\
\text { and IL-6), iNOS and NF-jB }\end{array}$ & 122 \\
\hline Anthronav & $\begin{array}{c}\text { Yogaraj guggul, Simhanad guggul, Methi, Nirgundi, } \\
\text { Chopchini, Pippali }\end{array}$ & Protein denaturation method & 123 \\
\hline PG201 (Laylas) & $\begin{array}{c}\text { Chaenomeles sinensis, Achyranthes japonica, } \\
\text { Acanthopanax sessiliflorus, Cinnamomum cassia, } \\
\text { Gentiana macrophylla, Clematis chinensis, Angelica } \\
\text { gigas Nakai, Cnidium officinale, Gastrodia elata, } \\
\text { Carthamus tinctorius, Saposhnikovia divaricata, } \\
\text { Dipsacus asperoides }\end{array}$ & $\begin{array}{l}\text { Western ontario and mcmaster } \\
\text { universities arthritis index } \\
\text { (WOMAC) pain, VAS score and } \\
\text { subscale score }\end{array}$ & 124 \\
\hline Polyherbal gels & $\begin{array}{c}\text { Aconiti Radix, Fagopyrum cymosum Meisn Zingiber } \\
\text { officinale }\end{array}$ & $\begin{array}{l}\text { Complete freund's adjuvant- } \\
\text { induced arthritis }\end{array}$ & 125 \\
\hline Polyherbal gels & Withania somnifera, Curcuma longa, Aloe vera & $\begin{array}{l}\text { Complete freund's adjuvant- } \\
\text { induced arthritis }\end{array}$ & 126 \\
\hline
\end{tabular}

\section{METHODOLOGY}

Published scientific literature about anti-arthritic PHFs was downloaded and retrieved from different databases such as Google scholar, Scopus, PubMed, Web of Science and floras of different countries. A total of 150 research articles were reviewed and during the screening process 75 articles published in English journals were selected containing the maximum relevant information. The use of different keywords, such as:traditionally used anti-arthritic plants, antiarthritic PHFs, arthritis in Asia, in-vivo and in-vitro antiarthritic studies assisted in the collection of the required information. Information regarding pharmacology, uses and phytochemistry of this formulation was summarized in the form of tables. To assure the validity of data, two co-authors reviewed all the information based on citation and language.

\section{RESULTS}

The herbal drugs were found to be potent and safe in treating RA effectively. There was a rising concern on the usage of herbs as whole. So the polyherbal formulations had been prepared and standardized by various companies and officially marketed as the RA 
drugs. These formulations were branded across in the medical market in the form of various formulations. These formulations utilize the ancient knowledge of Ayurveda and other systems of traditional medicine and incorporate them into the scientific research (Table 2). The polyherbal formulations are prepared using modern techniques and advanced machinery in large scale.

Table 2: Marketed polyherbal anti-rheumatic formulations

\begin{tabular}{|c|c|c|c|}
\hline $\begin{array}{c}\text { Formulation } \\
\text { name }\end{array}$ & $\begin{array}{c}\text { Type of } \\
\text { formulation }\end{array}$ & Ingredients & Manufacturer \\
\hline Artha cure & Oil & $\begin{array}{c}\text { Syzgium aromaticum, Aconitum ferox, Strychnos } \\
\text { nux vomica, Allium sativum, Cuscuta reflexa } \\
\text { Myristica fragrans }\end{array}$ & Be Sure Health Care $(\mathrm{P})$ Ltd \\
\hline Arthcure & Capsules & $\begin{array}{c}\text { Aloe vera, Colchicum leuteum, Operculina } \\
\text { terpethum, Crotalaria juncea, Piper longum } \\
\text { Myristica fragrans, Syzgium aromaticum, } \\
\text { Zingiber officinale, Black bitumen, Commipora } \\
\text { mukul, Aconitum ferox, Strychnos nux vomica, } \\
\text { Withania somnifera, Asparagus racemosus, } \\
\text { Allium sativum, Ciscuta refluxa }\end{array}$ & Be Sure Health Care (P) Ltd \\
\hline Majoon suranjan & Tablets & $\begin{array}{c}\text { Ipomea turpethum, Terminalia cheluba, } \\
\text { Colchicum luteum, Capparis spinosa, } \\
\text { Coriandrum sativum, Rosa damascus, Plumbago } \\
\text { zelanicum, Zingiber officinalis, Aloe } \\
\text { barbadensis, Apium graveolens, Convulvulus } \\
\text { scammony, Sepia latimanus, Foeniculum } \\
\text { vulgare, Lawsonia inermis, Piper nigrum, } \\
\text { Zataria multiflora, Ricinus communis }\end{array}$ & Qarshi herbal products \\
\hline Ortho joint oil & Oil & $\begin{array}{c}\text { Ricinus communis, Vign unguiculata, } \\
\text { Cinnamomum zeylanicum, Gaultheria } \\
\text { fragrantissima, Cinnamomum camphor, Menthe } \\
\text { arvensis, Wthania somnifera }\end{array}$ & SBS Biotech Ltd \\
\hline Rheuma off gold & tablets & $\begin{array}{c}\text { Commiphora mukul, Suvarna bhasma, Strychnos } \\
\text { nux vomica, Boswellia serrata, }\end{array}$ & Virgo UAP Pharma (P) Ltd \\
\hline Rumalaya forte & Tablet & $\begin{array}{c}\text { Boswellia serrata, Cammiphora wightii, } \\
\text { Alpiniaga galangal, Glycyrrhiza glabra, } \\
\text { Tribulus terrestris, Tinospora cordifolia, Vitex } \\
\text { negundi, Zinger officinalis }\end{array}$ & Himalaya Global Holdings Ltd. \\
\hline Rheumartho gold & Capsule & $\begin{array}{l}\text { Colchicum luteum, Withania somnifera, } \\
\text { Strychnos nux vomica, Boswellia serrata, } \\
\text { Ghanna sativa, Biotite calx, Nyctanthes arbor- } \\
\text { tristis, Calx of copper pyrites, Commiphora } \\
\text { mukul, Ipomoea digitata Calx of corat }\end{array}$ & Baidyanath \\
\hline Rumalaya & Liniment & $\begin{array}{c}\text { Psoralea caryofolia, Piper nigrum, Cinnamomum } \\
\text { camphor, Mentha arvensis, Carum capticum, } \\
\text { Sasamum indicum, Gaultheria fragrantissima, } \\
\text { Pinus longifolia }\end{array}$ & Himalaya Global Holdings Ltd. \\
\hline Sudard & Suspension & $\begin{array}{l}\text { Commiphora mukul, Pluchea lanceolata, } \\
\text { Paederia foetida, Vitex negundo, Zingiber } \\
\text { officinalis, Ricinus communis, Lepidium sativum, } \\
\text { Colchicum luteum, Smilax glabra, Strychnous } \\
\text { nuxvomica, Mineral pitch }\end{array}$ & $\begin{array}{l}\text { Anglo French Drugs and } \\
\text { Industries Ltd }\end{array}$ \\
\hline TBL-II & Tablets & Chineese herbs & $\begin{array}{c}\text { Zhong-Yue Herbal } \\
\text { Pharmaceutical Company }\end{array}$ \\
\hline
\end{tabular}




\section{CONCLUSION}

In the rising countries, increased cost of medicine as well as their side effects has become a great task when the public health is concerned. The scientific advancement carries with it the improvement in polyherbal formulations, through the study of various phytoconstituents and discovery of useful herbs combinations which work synergistically to produce desirable effect. Although polyherbal formulation is commonly used in many parts of the world, but scientifically it has not been explored. PHFs provide treatment of diseases in a holistic approach. Traditional healers and herbalists in Asia are using large numbers of anti-arthritic medicinal plants. India is the leading country in both ethno medicinal and pharmacological studies related with arthritis. Most of the anti-arthritic herbal formulations are used in the form of decoctions and poultices. Many herbal therapies are still under in vivo evaluation and have not been evaluated by clinical trials. Moreover, safety evaluations such as toxicological studies have not performed. There is need of time to evaluate polyherbal formulation using scientific methods such as clinical trial, possible bioactive compounds and mechanism of action for the future world. Only with correct and rational use, PHFs can exert the best effect in human health. This review reveals the diversity of polyherbal formulation which have been using for long time traditionally as well as in dosage form for the treatment of arthritics.

\section{Conflict of interests}

None declared

\section{REFERENCES}

1. Chitme RH, Patel PN. Open. Natl. Pro. J., 2009; 2: 615.

2. Sivakumar M, Chamundeeswari D, Susithra E. J. Pharm. Res., 2014; 8(7):986-989.

3. Ramalingam K, Mathiyalagan A, Subramanian S, Bharati RUD. J. Biochem. Tech., 2009; 1(4):108-113.

4. Goldring SR, Goldring MB. J. musculoskelet. Nuronal., 2006; 6(4):376-378.

5. Vaithiyar M. Rev. Edn., 1989:25-114.

6. Sherwani SK, Bokhari TZ, Sualeh M, Kausar R, Muhammad H, Nangyal H. Global J. Phamacol., 2013; 7(3):360-364.

7. Nair V, Sing S, Gupta YK. J. Pharm. Pharmacol., 2010; 62(12):1801-1806.

8. Pretzel D, Pohlers D, Weinert S, Kinne RW. Arthritis Res. Ther., 2009; 11:R25.
9. Chauhan S, Kishore L, Kaur N, Singh R. Res. Rev; J. Pharm. Pharma. Sci., 2015; 4(3):10-22.

10. Firestein GS. Nature. 2003; 423:356-361.

11. Pinals RS, Masi AT, Larsen RA. Arthritis Rheum., 1981; 24(10):1308-1315.

12. Burnett BP, Levy R, Cole BJ. J. Knee. Surgery., 2006; 19(3):191-197.

13. Mujapara AK, Jarullah B. Intern. J. Genetics., 2009; 1(2):6-9.

14. Kaur E, Kaur J. Frost Sullivan. 2009; 165362056.

15. Zeng QY, Chen R, Darmawan J, Xiao ZY, Chen SB, Wigley R. Arthritis Res. Ther., 2008; 10(1) :1-11.

16. Kaur A, Nain P, Nain J. Int. J. Pharm. Pharm. Sci., 2012; 4(4):44-57.

17. Lubberts E, Joosten LA, Oppers B, Berssellaar VL, Connen-de Roo CJ, Kolls JK, Schwarzenberger P. J. Immunol., 2001; 167(2):1004-1013.

18. Paget SA, Gibofsky A. AM. J. Med., 1979; 67:961-970.

19. Van der Linden MP, Van der Woude D, Ioan-Facsinay A, Levarht EW, Stoeken- Rijsbergen G, Huizinga TW. Arthritis Rheum., 2009;60:2232-2241.

20. Fransen M, Bridgett L, March L, Hoy D, Penserga E, Brooks P. Int. J.Rheum. Dis., 2011; 14 (2):113-121.

21. Nevitt MC, Xu L, Zhang Y, Lui LY, Yu W. Arthritis Rheum., 2002; 46(7):1773-1779.

22. Madry H, Luyten FP, Facchini A. Arthroscopy., 2012; 20:407-422.

23. Grenier S, Bhargava MM, Torzilli PA. J. Biomechan., 2014; 47:645-652.

24. Gaston JSH. Rheumatic Diseases:Immunological Mechanisms and Prospects for New Therapies. Cambridge University Press. 1999.

25. Glass DN, Giannini EH. Arthritis Rheum., 1999; 42(11):2261-2268.

26. Crofford LJ. Arthritis Res. Ther., 2013; 15(3):S2.

27. Schett G, Emery P, Tanaka Y, Burmester G, Pisetsky DS, Naredo E. Ann. Rheum. Dis., 2016; 75:1428-1437.

28. Gerards AH, de Lathouder S, de Groot ER, Dijkmans BA, Aarden LA. Rheumatology. 2003; 42:1189-1196.

29. Rudwaleit M, Yin Z, Siegert S, Grolms M, Radbruch A, Braun J. Ann. Rheum. Dis., 2000; 59: 311-314.

30. Cronstein BN. Ann. Rheum. Dis., 2006; 65:421-422.

31. Hasko G, Cronstein B. Front. Immunol., 2013; 4:85.

32. Lopez-Olivo MA, Siddhanamatha HR, Shea B, Tugwell P, Wells GA, Suarez-Almazor ME. Cochrane Database Syst. Rev., 2014.

33. Carneiro SC, Cassia FF, Lamy F, Chagas VL, Ramose-Silva M. J. Eur. Acad. Dermatol. Venereol., 2008; 22:25-29.

34. Cheng HS, Rademaker M. Psoriasis. 2018; 8:21-29.

35. Conway R, Carey JJ. World J. Hepatol., 2017; 9: 10921100. 
36. Monaco C, Nanchahal J, Taylor P, Feldmann M. Int. Immunol., 2015; 27:55-62.

37. Weinblatt ME, Keystone EC, Furst DE, Moreland LW, Weisman MH, Birbara CA. Arthritis Rheum., 2003; 48:35-45.

38. Roda G, Jharap B, Neeraj N, Colombel JF. Clin. Transl. Gastroenterol., 2016; 7:e135.

39. Goh L, Jewell T, Laversuch C, Samanta A. Rev. Bras. Reumatol., 2013; 53:501-515.

40. Kim GW, Lee NR, Pi RH, Lim YS, Lee YM, Lee JM. Arch. Pharm. Res., 2015; 38:575-584.

41. Oldfield V, Dhillon S, Plosker GL. Drugs, 2009; 69:609-632.

42. Navarro-Millan I, Singh JA, Curtis JR. Clin. Ther., 2012; 34:788-802.

43. Smolen JS, Schoels MM, Nishimoto N, Breedveld FC, Burmester GR, Dougados M. Ann. Rheum. Dis., 2013; 72:482-492.

44. Hench PS, Kendall EC, Slocumb CH, Polley HF. Arch. Intern. Med., 1950; 85:545-666.

45. Barnes PJ. British J. Pharmacol., 2006; 148:245-254.

46. Mundell L, Lindemann R, Douglas J. BMJ Open Qual., 2017; 6:e000209.

47. Youssef J, Novosad SA, Winthrop KL. Rheum. Dis. Clin. N. Am., 2016; 42:157-176.

48. Clarke TC, Black LI, Stussman BJ, Barnes PM, Nahin RL. Trends in the Use of Complementary Health Approaches Among Adults:United States, 2002-2012; U.S. Department of Health and Human Services, Centers for Disease Control and Prevention, National Center for Health Statistics: Hyattsville, MD, USA, 2013.

49. Barnes PM, Bloom B, Nahin RL. Complementary and Alternative Medicine Use Among Adults and Children:United States, 2007; National Health Statistics Reports; U.S. Department of Health and Human Services, Centers for Disease Control and Prevention, National Center for Health Statistics: Hyattsville, MD, USA, 2008.

50. Ben-Arye E, Frenkel M, Klein A, Scharf M. Patient Educ. Couns., 2008; 70:395-402.

51. Ekor M. Front. Pharmacol., 2014; 4:177.

52. Cascao R, Vidal B, Raquel H, Neves-Costa A, Figueiredo N, Gupta V. Autoimmun. Rev., 2012; 11: 856-862.

53. Venkatesha SH, Dudics S, Astry B, Moudgil KD. Pathog. Dis., 2016; 74:ftw059.

54. Nanjundaiah SM, Venkatesha SH, Yu H, Tong L, Stains JP, Moudgil KD. J. Biol. Chem., 2012; 287: 22216-22226.

55. Zhang RX, Fan AY, Zhou AN, Moudgil KD, Ma ZZ, Lee DY. J. Ethnopharmacol., 2009; 121:366-371.
56. Busbee PB, Rouse M, Nagarkatti M, Nagarkatti PS. Nutr. Rev., 2013; 71:353-369.

57. Che CT, Wong MS, Lam CW. Molecules. 2016; 21:239.

58. Venkatesha SH, Yu H, Rajaiah R, Tong L, Moudgil KD. J. Biol. Chem., 2011; 286:15138-15146.

59. Che CT, Wong MS. Nat. Prod. Commun., 2015; 10:2189-2194.

60. Che CT, Wang ZJ, Chow MSS, Lam CWK. Molecules. 2013; 18(5):5125-41.

61. Risberg K, Fodstad Ø, Andersson Y. PLoS One. 2011; 6 (9):23-34.

62. Ramaiah M, Chakravathi G, Yasaswini K. Pharmacogn J., 2013; 5(3):130-4.

63. Ajazuddin, Saraf S. Pharmacog. Res.,2010; 2(5):31822.

64. Reddy MS, Reddy DRK, Prasad NAV. Herbal and pharmaceutical drugs enhanced with probiotics. 2000; US006080401A

65. Bhope SG, Nagore DH, Kuber VV, Gupta PK, Patil MJ. Pharmacog. Res., 2011; 3(2):122-129.

66. Benzie IFF, Wachtel-Galor S. Herbal Medicine: Bimolecular and Clinical Aspects, 2nd edn. CRC Press/Taylor \& Francis 2011.

67. Spinella M. Altern. Med. Rev., 2002; 7:130-137.

68. Chorgade MS. Drug Discovery and Development: Drug development Vol. 2. John Wiley and Sons Inc; Hoboken, New Jersey: 2007.

69. Parasuraman S, Thing GS, Dhanaraj SA. Pharmacog. Rev., 2014; 8(16):73-80.

70. Sarwar M, Attitalla IH, Abdollahi M. Asian J. Anim. Vet. Adv., 2011; 6(8):867-883.

71. Kavitha AN, Deepthi V, Nayeem N. Pharmacophore 2013; 4(5):175-180.

72. Rastogi S, Chiappelli F, Ramchandani MH, Singh RH, editors. Evidence-based Practice in Complimentary and Alternative Medicine Perspective, Protocols, Problems and Potential in Ayurveda. New York City:Springer; 2012.

73. Rasool M, Sabina EP. Phytother. Res., 2007; 21(9): 889-894.

74. Rajashekaran A, Subramaniam I, Govindarajan A, Ramasamy A. J. Rheumatol. Arthritic Dis., 2017; 2(4): 1-12.

75. Srivastava N, Dashora N, Menaria J, Kumar N. Int. J. Pharm. Phytopharmacol. Res., 2016; 6(5):72-76,

76. NarkeVE, Athavale NV, Khisti UV, Nipanikar SU. World J. Pharm. Res., 2016; 5(6):1668-1681.

77. Pramanik J, Giri I, Maiti MK, Das S, Dasgupta P. J. Pharmacog. Phytochem., 2018; 7(6):318-322

78. Panchal P, Hirani K, Bhuva V, Patel A. Pharma Sci. Monitor.2019; 10(3):117-129. 
79. Sumanth M, Anusha, Swetha S. Indian J. Tradit. Knowl., 2012; 11 (4):704-713.

80. Sree A, Shibina KA, Hameed J. J. Pharm. Sci. Res., 2017; 9(8): 1281-1282.

81. Das C, Bose A, Das D. J. Tradit Complement. Med., 2021; 11:228-237.

82. Xian-Ju H, Wang J, Muhammad A, Hai-Ying T, DaGui W, Li J. J. Ethnopharmacol., 2021; 272:113953.

83. Soni H, Patel G, Shah M, Panchal M, Murti K. Int. J. Pharmacol. Clin. Sci., 2013; 2:14-8.

84. Nagarkar B, Jagtap S. BMC Complement. Alter. Med., 2017; 17:194.

85. Balkrishna A, Sakat SS, Joshi K, Paudel S, Joshi D, Joshi K. Front. Pharmacol., 2019; 10:659.

86. Bhatt L, Maithani S. Int. J. Nutr. Pharmacol. Neurol. Dis., 2017; 7:88-93.

87. Shyni GL, Ratheesh M, Sindhu G, Helen A. Immunopharmaco. Immunotoxicol., 2010; 32(4):569-575.

88. Elechi-Amadi KN, Brown H, Briggs ON, Nwachuku EO, Opusunju BH. Asian J. Med. Princ. Clin. Pract., 2020; 3(2): 11-18.

89. Elechi-Amadi KN, Nwachuku EO, Tamuno-Emine DG, Nduka ON. J. Complement. Alter. Med. Res., 2019; 7(4): $1-8$.

90. Aswathy IS, Krishnan S, Peter J, Sabu AV. J. Ayurveda Integr. Med., 2021; 12:20-27.

91. Vador $\mathrm{N}$, Vador $\mathrm{B}$, Rajgor $\mathrm{N}$. Indian J. Pharm. Pharmacol., 2020;7(1):43-47.

92. Singh S, Nair V, Gupta YK. Indian J. Med. Res., 2011; 384-388.

93. Tripathi RK, Vaidya PH, Raote S, Desai MM, Chawda MB, Uchil D. J. Clin. Diagn. Res., 2017; 11(10): FC06-FC10.

94. Patel N, Patel J, Patel A, Paneliya AKM. World J. Pharma. Med. Res., 2020; 6(6):164-172.

95. Subash KR, Cheriyan BV, Parvathavarthini S, Bhaarati GM, Venugopal V. Indian Drugs.2012; 49(10): 18-24.

96. Asad M, Prasad K, Thomas L, Kamath JV. Iranian J. Pharmacol.Thera., 2007; 6(1); 71-75.

97. Nipanikar SU, Saluja M, Kuber VV, Kadbhane KP, Chopra A, Khade NR. J. Ayurveda Integr. Med., 2013; 4:33-39.

98. Zegota Z, Gozdzik J, Głogowska-Szela J. Advances Orthopedics. 2021; 5589597.

99. Singh S, Kumar R, Jain H, Gupta YK. Phcog. Res., 2015; 7:188-92.

100. Ahmad S, Mohiuddin E, Shah SMA, Akram M, Amjad M, Nisar J. Int. J., 2020:1-8

101. Parisi V, Vassallo A, Pisano C, Signorino G, Cardile
F, Sorrentino M. Molecules. 2020; 25:2255.

102. Petchi RR, Parasuraman S, Vijaya C, Gopala Krishna SV, Kumar MK. J. Basic Clin. Pharma., 2015;6:77-83.

103. Bansod MS, Kagathara VG, Pujari RR, Patel VB, Ardeshna HH. Int. J. Pharm. Pharm. Sci., 2011; 3(2): 186-192.

104. Mohan Rao TJ, Chandira RM. Indian J. Natural Sci., 2020; 10(61):27258-27272.

105. Kumari SJ, Satyanarayana V. Int. J. Green Pharm., 2019; 13(3):242-248.

106. Mian SS, Upadhyay TS. Biomed. Pharmacol. J., 2021; 14(3):1219-1229.

107. Chimagave SS, Jalalpure SS, Kurangi BK. Indian J. Health Sci. Biomed. Res., 2020; 13:120-6.

108. Shelar MK, Patil MJ, Metri CM, Bhujbal SS. European J. Mol. Clin. Med., 2020; 7(11):7461-747

109. Ahalya S, Venkatesh BA, Vijayasarathi R, Shalini TV. J. Ayurveda Integr. Med. Sci., 2017; 6:34-41.

110. Patel SS, Shah PV. J. Ayurveda Integr. Med., 2013; 4:86-93.

111. Shen X, Li C, Zhao H, Li S, Chen J, Kobayashi Y. J. Ethnopharmacol., 2011;134:399-405.

112. Zhang RX, Fan AY, Zhou AN, Moudgil KD, Ma ZZ, Lee DY. J. Ethnopharmacol., 2009; 121: 366-71.

113. Jeoung BR, Lee KD, Na CS, Kim YE, Kim B, Kim YR. BMC Complement. Altern. Med., 2013; 13:47.

114. Balkrishna A, Sakat SS, Joshi K, Paudel S, Joshi D, Joshi K. Scientific Reports. 2019; 9:8025.

115. Sumantran VN. Phytother. Res., 2011; 25:1375-1380.

116. Suva MA. Indian J. Pain. 2018; 32:16.

117. Chakradhar NS. Drug Inv. Today 2018; 10:16171625.

118. Haroyan A. BMC Complement. Altern. Med., 2018; 18:7.

119. Kizhakkedath R. Mol. Med., 2013; 8:1542-1548.

120. Paramanick D. J. Pharmacopunct., 2017; 20:89.

121. Aswathy IS. J. Ayurveda Integr. Med., 2019; 139.

122. Kumar R. Planta Med., 2016; 82:1403-1409.

123. Ashok Kumar BS, Vamshikrishna N, Saran G, Sanjay T, Dhanusha KA, Harshada R. Int. J. Trad. Herb. Med., 2013; 1(6):177-180.

124. Yoo WH, Yoo HG, Park SH, Baek HJ, Lee YJ, Shim SC. Rheumatol. Int., 2014; 34(10):1369-78.

125. Cheng-Lin S, Yong-Xian Z, Ping-Shan W, Da-Yong P, Wen-Kun Z. J. Biomater, Tissue Eng., 2015; 5(11):914-917(4).

126. Ying C, Hong L, Yu-Ping D, Jian W. J. Biomater, Tissue Eng., 2015; 5(4):342-346(5). 